Abstract The availability of same-sex weddings poses a number of personal and political dilemmas for couples who decide that they wish to go through a ceremony of recognition or civil

partnership. In this article I argue that British couples are acutely aware of the political ramifications of their decisions and I focus attention on the interplay between the personal and political in decisions that couples make on the types of ceremony they want. For example, some couples want very prominent, high profile weddings while others insist that same-sex couples do not need to display their relationships in public ceremonies because this merely emulates heterosexual practices. These issues are explored through qualitative interviews with same-sex couples which collected stories on 54 same-sex ceremonies held in the UK.

Keywords civil partnership, gay men, lesbians, personal politics, same-sex weddings

\title{
'Can I Be Bridesmaid?' Combining the Personal and Political in Same-Sex Weddings
}

Brenda: Well the night it [the Civil Partnership Bill] went through the [House of] Lords for the last time, Wednesday week or whenever it was, I was all on my own here. Joy was in America and it was late at night and I went, as I always do, to see if I had got any emails before I switch off and go to bed. And the stop press from Stonewall came through saying it had happened and I was here on my own. I had no one to tell and felt like rushing out in the street and going 'Hooray!' and of course this is farming country so everybody was asleep and it was dark. And all my friends would be in bed and I was like 'Oh my God!' So I emailed my sister who was the only person, she emails me from work quite often, and I said to her 'This [has] happened [and] I don't really believe it'. And she just emailed back the next day a single line saying 'So can I be bridesmaid?' (Aged 59, relationship of 44 years, professional)

Sexualities http://sex.sagepub.com Copyright @ 2008 SAGE Publications (London, Thousand Oaks, CA, New Delhi, Singapore and Washington DC) Vol II(6): 763-778 DOI: I0.I I77/I3634607080969I7 
This quotation from Brenda captures a number of the themes that I wish to pursue in this article. First it identifies a specific moment in 2004 when it became clear that civil partnership legislation would actually be passed in the UK and same-sex couples would be entitled to the same rights of legal partnership as heterosexual couples. ${ }^{1}$ Brenda's response records the shock she felt because few activists and commentators (Weeks, 2007) were confident that the Bill would succeed in the House of Lords where there was most opposition from established religious bodies and homophobic peers. It seemed likely that there would be enough opposition to stall the legislation if not defeat it permanently. ${ }^{2}$ So Brenda felt surprise and elation at the success of the Bill. Along with all the lesbians and gay men we interviewed for our research project at the time, she felt immense pleasure that at last same-sex relationships would be recognized as legitimate, meaningful and equal. But this 'political' appreciation of the turn of events was immediately interpreted through a personal lens. In other words Brenda was faced with the real decision in her personal life about whether to enter into a civil partnership with her partner of 44 years standing. Her sister's response to her email had turned a political event into one of overwhelming personal salience. Not only did her small question of bridesmaids raise the larger one of whether Brenda and her partner Joy would want to get legally married, ${ }^{3}$ it also opened up a raft of potential decisions about the type of ceremony to have and what kind of 'message' (if any) their ceremony should impart. Equally important was the question of whether there were ways of adopting a state-sanctioned process while keeping or creating new, distinctive lesbian or gay conventions around partnering. This, I suggest, is the contentious personal and political terrain that many same-sex couples in the UK are negotiating. Civil partnership and its forerunners in the form of (non-legal) commitment ceremonies and local authority partnership registration ${ }^{4}$ provide a complex option for couples. Decisions about whether to hold a ceremony, register a partnership or to go down the route of civil partnership all involve consideration of wider sexual politics, personal aspirations and desires, and ideas about how to retain integrity and principles concerning life-styles. People find themselves considering all these elements when making these important life decisions and so studying the choices they make when confronted by these options illuminates greatly how this contemporary terrain is navigated.

In this article I shall focus particularly on decisions taken about styles of weddings because the delicate negotiations that occur between partners are not simply about colour schemes and venues, but are also about precisely how 'political' their wedding is going to be and, further, what kind of political statement it will make (if any). Thus the point about the wedding is that it signals the kind of relationship that couples hope to sustain in a marriage. The wedding is a window on the marriage, and 
although ultimately the marriage may be relatively private, the wedding is usually a public event through which couples can give important signals to friends, family and wider communities. I shall also argue that the negotiated choice of ceremony is linked to a couple's style of political engagement. In contrast to the findings of Hull (2006) and Lewin (1998) in the USA, this study found that almost all the interviewees were 'saturated' with insights about the political nature of their decisions. Kathleen Hull, for example, asks whether 'same-sex couples' use of marriage-related cultural practices [should] be read as a kind of political action, even though the couples themselves usually do not think of their choices in this way' (Hull, 2006: 15). However, in the British context such a question seems out of place since the couples in our study not only saw what they were doing as political in various ways, but they were also highly aware of the problems of managing their personal desires in the context of contemporary political discourses. What is more, this awareness was spontaneously voiced by our respondents in the context of open-ended discussion about their plans for their ceremony or when speaking about how they would tell their friends and family about their plans.

\section{The study of gay and lesbian marriage}

As I have already noted, when this study was originally conceived in 2002 it did not seem likely that the Labour government would extend the right to marry to same-sex couples. ${ }^{5}$ It was clear that some lesbian and gay couples in the UK had become tired of waiting for change and were creating their own commitment ceremonies notwithstanding their knowledge that these would have no legal standing. So there was a grass-roots movement which was ahead of legal change and it was this movement we hoped to capture in our study. We were following to some extent in the footsteps of Ellen Lewin (1998) who had published her anthropological study of same-sex commitment ceremonies in the USA. Her research showed the ways in which US couples were taking measures into their own hands in order to achieve recognition for their partnerships - at least within their communities of friends, families and colleagues. The idea of getting married was therefore gaining currency and it was clear that it was not necessary to wait for the government to act before, at a grass-roots level, people could take up the ritual most associated with heterosexual partnership and redefine it as something of value for same-sex couples. So the study ${ }^{6}$ set out to explore how and why lesbian and gay couples were creating their own ceremonies and also whether they were registering their partnership with their local authority. We were also concerned to explore their views on the right to marry legally and we hoped that our findings might contribute to ongoing debates on the need (or otherwise) for legal 
reform of the marriage laws in England and Wales. We were overtaken by events. Our early interviews with couples record their frustration with the lack of reform but also the feeling that little would happen in the immediate future. Then, part way through the interview process the Civil Partnerships Bill was not only introduced into Parliament, but in November 2004 it became law. The government then announced that the first civil partnerships would not be available until December 2005. This created a 12-month limbo for our research project - as well as for many couples. It meant that it was hard to keep recruiting couples who were having commitment ceremonies as most were deciding to wait for civil partnership (which was too late for the lifetime of our project). For some couples who had already made substantial wedding plans, we found that they went ahead anyway but it posed for them questions of whether they would do it all over again when it became 'legal'. Others decided to go ahead with marrying abroad (The Netherlands, Canada or Belgium) because they really could not wait owing to the ill health of a partner, or for immigration purposes. Others postponed their ceremonies and so we found ourselves interviewing couples about their plans rather than interviewing them about their actual experiences.

The study was based on in-depth interviews with 37 couples and 17 individuals. We recruited people through magazines like Diva or Gay Times, $^{7}$ as well as by contacting some relevant local organizations and leaving leaflets in places such as specialist bookshops or at gay pride marches. We hoped to interview couples together because we were interested in how they might present their shared history, but we also felt strongly that we would not want to exclude anyone because they could not be present with their partner. This means that we have information on 54 relationships but some of the data were collected from just one member of the couple and so the texture of the interviews varies. Of our 37 couples, 10 were gay couples and 27 were lesbian couples. Of the 17 individuals, 10 were men and seven were women. The majority of our sample (in a ratio of 8:1) was what might be called broadly middle class in terms of occupation, education and housing type. Also all, save one, described themselves as being of white ethnicity. This bias towards white middle-class respondents is likely to reflect our sampling procedures and also the fact that we took the decision to exclude London from our strategy. Attempts were made to extend our reach in larger cities such as Manchester but these were unsuccessful in the timeframe we had. All the interviews were tape recorded, transcribed and anonymized, so all the names that appear in this article are fictional. In order to preserve anonymity further we avoid using place names, exact professions or jobs, and any other potentially revealing information. 


\section{The shape of ceremonies}

I argued earlier that the kind of ceremonies that the couples 'chose' were a reflection of their political style. But it would be an oversimplification to suggest simply that some kinds of ceremonies signify a neo-liberal politics while another signifies a queer stance. This is because couples were often engaged in negotiations with each other while also balancing their personal feelings with their political views. We therefore realized very quickly that 'choice' of ceremony was not necessarily at all simple. So at the basic level the partners had to negotiate with each other. This meant that although one might want a flamboyant party, the other wanted only a dozen people there. So each ceremony was a compromise rather than a simple reflection of a congruous desire. Moreover some wanted weddings that would be as 'camp as Christmas' yet realized they also wanted parents or other relatives to come. So couples were very attentive to the needs and feelings of kin (Smart, 2007). Every ceremony was therefore a compromise between competing desires and sensibilities and so required careful analysis on our part. But they were also a compromise with and between each couple's political sensibilities. This means that sometimes one partner saw the wedding as an opportunity to take a stand against heterosexist and homophobic assumptions; while the other was more concerned with ensuring they would simply be recognized as a 'real' couple. Other couples felt that their political commitment required a small, quiet gathering while yet others, who also saw their wedding in equally political terms, wanted a very large public party. In order to explore some of these issues I have analysed the different types of ceremony held by these couples using an overarching notion of 'personalpolitical style'. Every couple engaged in a negotiation between competing concerns, but in the end certain factors came to weigh more heavily and this produced a particular form of wedding. This does not mean that some ceremonies were better than others, nor that some forms reflected more radical or progressive politics. I am not concerned with measuring these events on that sort of scale. Rather I am interested in what the final 'choices' meant in terms of how these couples negotiated the personal and the political and how they wanted to present their relationship to the wider world.

Using this notion of 'personal-political style' I have elicited four forms or styles of wedding from the data. I refer to these as 'regular' weddings (18 out of 54), 'minimalist' weddings (14), 'religious' weddings (13), and 'demonstrative' weddings (9). In doing this I am seeking to show how the mixture of the personal and the political can take different shapes while still conveying significant meanings. I am adopting a strategy quite different to that of Hull (2006) who acknowledges the differences in same-sex 
weddings but who focuses on what they have in common (or their core components) in order to get at their symbolic political significance. In exploring differences I hope to throw light more on the personal negotiations that go on between couples and their principles, rather than focusing on the (potential) political impact on wider society.

\section{Regular weddings $(\mathrm{n}=18)$}

The weddings I refer to as 'regular' were those held in a secular environment, led by a designated celebrant and followed by a modest party or gathering. The celebrant might have been a humanist, occasionally a gay priest operating in a non-religious capacity, or it was more often a registrar. In this type of ceremony the basic shape was usually predetermined in that there would be a 'congregation' made up of a mixture of family and friends; witnesses or at least a few 'special' people who would take on extra duties such as giving readings; an exchange of rings; and an exchange of promises or statements of commitment from the couple. Changing or blending names was rare. Typically couples explained to us that they contacted the celebrant or registrar and that they were sent a booklet, which outlined a format and offered possible forms of words or indicated where a reading or poem might occur. Couples could then either choose the wording they liked or substitute their own. After the actual ceremony couples would typically have a party (to which more people might come) or a meal with just a special group of people.

Judy: Yes they give you a booklet and you basically sort of they give you like several different versions and you mix and match what you want. It is all right; it is a bit too much like marriage vows for me; it is a bit too straight for me, do you know what I mean? So there was not a lot about respect in it really. There was just about love and love is wonderful and so yes, it was all right. (Aged 31, professional, relationship of 4 years)

Stella: We used Northtown register office and basically took their standard format of ceremony and we actually thought it was a really good system, their mix and match system if you like, [where there] is the standard framework and you can drop into it a reading here and a reading there. And we quite liked the DIY part of it . . . you build your own ceremony. And I also quite liked the fact that there was a whole load of suggested readings, particularly for me who is not particularly into poetry and those sorts of things. I think I would have been hard put to find anything as nice as we ended up with. (Aged 45, professional, relationship of 8 years) 
Cameron: The way they organized it for us it sort of mirrored, if you like, a standard sort of wedding in that we got everybody there for about 3 in the afternoon we had a ceremony, which we choreographed a little then after the ceremony everyone had drinks. And then we went in for a formal dinner with the seating plan being the usual and we could not resist the seating [plan] it is the best [bit] of any wedding organizing that. And then after that there were speeches, there was music, and then it was time to go home. So it mirrored a wedding if you like but there was no religious input and it was outside. (Aged 44, professional, relationship of 15 years)

For the majority of these couples who were following the 'regular' wedding route the issue of whether they were just falling into line with a standard heterosexual marriage ritual was important. A few said that they did not care about this and one couple said they wanted their ceremony to be as much like a heterosexual wedding as possible in order to establish that it was truly meaningful to their parents. But most felt edgy about this issue and took comfort from the fact that they could choose their own words and readings or poems. Some hated the term vows, seeing them as particularly resonant of heterosexual practices; so they used the term 'promises' or wrote statements about their commitment to their partner. Judy, quoted earlier, was happy with the references to love, although she would have liked a little more about respect. In saying this it is clear that she saw an emphasis on respect as indicating a particular lesbian value but also as a signal about the nature of her relationship. For most in this group the ability to 'build their own ceremony' meant that they could import enough lesbian or gay specificity into the occasion to be satisfactory. All these couples were glad that they did not have to work from scratch and it seemed that the ultimate goal of recognition (personal, political and legal) was more important than the fact that, superficially, it might not look very different from a heterosexual wedding. For the next group however only the most minimal ritual was acceptable.

\section{Minimalist weddings $(n=14)$}

Those who wanted a minimalist wedding tended to be couples who had been together for many years and who felt that they really only wanted the legal protections that would come from civil partnership. With the exception of three lesbian couples who had held entirely private but very romantic ceremonies and one gay man whose wedding was very basic because his partner was dying, all of these couples were resolutely against visible ceremony and ritual. Some felt they just did not want their personal feelings made public but most were also worried about recreating a heterosexual practice through this kind of display (Finch, 2007). 
Hilda: $\quad$ No it is just going to be a plain signing nothing else. We do not want any frills. We are really doing it just for legal reasons not anything else ...

Yvette: We are boring old farts the pair of us.

Interviewer: You do not want an excuse for a big party or anything like that?

Yvette: $\quad$ No, a big tube of Smarties I suppose.

Hilda: Or we have a bottle of champagne we can open, but apart from that ...

Yvette: Buy some chocolates.

Hilda: That is damn decent of you!

Yvette: You can buy two packs. Oh and Liquorice Allsorts. What more can I say?

Hilda: Oh yes, yes, devotion. (Aged 75 and 62, retired, relationship of 8 months)

The idea that making the private public was distasteful or politically dubious was a significant theme with this group. This sentiment did not appear to be related to concerns about homophobic responses to going public; rather there was just a feeling that it was no one else's business. These couples spoke of just going into the registry office and signing the document with their witnesses. For this group, civil partnership was all about securing legal rights and protections and they did not wish to incorporate it into some kind of romance or ceremony of recognition as they felt that their relationships were already sufficiently established in their personal community (Pahl and Spencer, 2004). Thus this choice of absolute minimalism was also a strong statement about the quality of their existing relationships, since this instrumentalism signified strength and commitment.

But minimalism could also be ultra romantic. Three younger lesbian couples who had ceremonies with only few others present, (in one case on the 'Maid of the Mist' amongst unwitting strangers and with another the only witness was a blackbird) opted for privacy as a way of maximizing personal significance. This particular minimalist style emphasized interpersonal trust combined with a rejection of any need for community support or salience. In both Hull's and Lewin's terms, these weddings might not be identified as political events at all because there were no witnesses and the couples therefore did not appear to be making any kind of social or public statement. Yet in one sense this rejection of the social display element of weddings (with all the social expectations that this can import) may be the most politically radical of all, precisely because it can evade those constraining expectations. 


\section{Religious weddings $(n=13)$}

In this group are included those who wanted to create ceremonies that were conducted by a religious or ordained celebrant and who wanted their union to be blessed and hence performed in the eyes of God even if it was not recognized by an established church or religion. But in addition I have included three couples who chose to have pagan or shamanic ceremonies because for them the spiritual aspect of the ceremony was vital even though they were not practising pagans. The position of the Church of England on same-sex marriage is clear and no ordained priest is allowed to officiate at such a wedding or even bless such a union. However, our couples found that some clerics would officiate (albeit at some risk) and many religious lesbians and gay men turned to the Metropolitan Community Church (hereafter MCC) as an alternative to mainstream churches. The MCC featured in five of our interviews with religious couples.

It was interesting that the desire to have a religious component did not lead automatically to a conventional type of ceremony and the struggle against adopting a ready-made heterosexual model of ritual was resonant here too.

Kurt: I cannot stress enough this thing I had, I do not want a heterosexual copy type thing but inevitably it sort of leaned that way. And we got wedding presents and they played all these games trick and treat or whatever - with us, with the car . . . and oh it was gorgeous. And yes I will think back afterwards and it was fabulous. (Aged 37, professional, relationship of 12 years)

Aidan: Derek does not want a heterosexual wedding whereas I . .

Derek: I think you cannot help but have. (Aged 59 and 46, retired, relationship of 22 years)

In appearance these weddings might have looked a lot like conventional heterosexual marriage ceremonies. The couples wore special outfits, exchanged rings, exchanged vows and saw their commitment to each other in the context of a wider commitment to God (or a spiritual entity). For Kurt and Thomas, as well as for Aidan and Derek, there was a reflexive self-awareness that in spite of their wish not to follow heterosexual conventions it was hard not to 'lean' that way. In some instances couples changed the words of familiar hymns, turning Him into Her in order to subvert convention. In less formal ceremonies they might opt to use gay 'anthems' such as The Weather Girls' 'It's Raining Men'; Celine Dion's 'My Heart Will Go On', or even Cliff Richard's 'Congratulations' and mix these with traditional hymns. The choice of such songs signified difference and imported elements of some gay or lesbian cultures into the mainstream and in this manner destabilized heterosexual expectations. These 
weddings were therefore a site of symbolic struggle in terms of public politics, while also being extremely significant at a personal level.

The pagan and shamanic rituals had a less conventional appearance because practices such as baking the bread for the congregation, the simple Hessian outfits, and plaiting the twine to bind hands together are not everyday occurrences. However, these practices would almost certainly have been the same for heterosexual couples marrying in these traditions and so these rituals were not automatically more radical - in terms of sexual politics - than the Christian ones described earlier. But the choice of these minority spiritual practices was nonetheless an important way to represent difference and a way of signalling commitment without subscribing wholeheartedly to the expectations of conventional heteronormativity.

Richard: We had to make robes for the ceremony.

Will: $\quad$ It had to be natural material like hessian, stuff like that ...

Richard: I also made ropes for J, the one who did the ceremony, and her husband who is the shaman; I made them their ropes as well. And then on the day of the actual ceremony before the ceremony could start ... J went out and blessed all the garden and put a ring of rose petals in which the ceremony was in. I had to make a velvet cloth for us to stand on which had the sun on it and J had one on the altar that she had with a pentangle ... And then before the ceremony, individually, all four of us had to sit in a bath with salt water and basil leaves to cleanse and purify the body and then put the robes on. It was supposed to be bare foot but it was just too cold.

Will: $\quad$ Not in winter; no way! (Aged 42 and 34, skilled manual, relationship of 16 months)

Ellen Lewin argues that 'these rituals have the potential . . to be simultaneously conservative and subversive, to enshrine presumed traditional values as they also satirize and undermine them' (1998: 243). These religious ceremonies do seem to fit this description particularly well, except that we found no intimations of satire at all. All of the couples who chose these types of ceremony subscribed genuinely to a religious belief or really did want another (spiritual) dimension added to their ceremony. They were genuinely seeking a 'specialness' even if they were rejecting established religion. Satire was therefore not part of their repertoire of meanings.

\section{Demonstrative weddings $(\mathrm{n}=9)$}

Demonstrative weddings were those that took an incredible amount of planning, becoming almost military campaigns in some cases. The main 
defining characteristic of these weddings was the full-on public nature of them. These couples wanted to make their personal commitments as public as possible and saw this public quality as an expression of their sexual politics. In this regard they were the complete antithesis of the minimalists who often had both personal and political objections to public display. Couples in this category often planned to have complementary or matching wardrobes, often had rings especially made, invited large numbers of people and might hire a wedding planner. They set the ceremony or party in a very grand or unusual setting (e.g. a museum), the celebrations might go on for several days, unusual cakes would appear, or the whole affair would simply be tasteful but terribly expensive.

Phil: We will have rings oh yes. We have looked at the Gucci rings so they are going to be good rings. Yes I just want it to be very stylish. So I have looked at the rings and I have looked at the suits and I have started to negotiate having Philip Treacy hats, that kind of thing rather than rented tuxedos ... all I know is that I want a really nice Vivienne Westwood suit; that is all I know so far. (Aged 36 , professional, relationship of 3 years)

Phil (and his partner) were wealthy and so could afford to spend a lot of money on their wedding. But it was not this quality alone that made their wedding plans extravagant. Rather it was this factor combined with the intense planning they were undertaking to make it a tasteful public display. The important feature for these couples was that their wedding could not possibly be overlooked. At the other end of the spectrum were Celia and Rachel who planned their wedding in the utmost detail but according to entirely different, less material, values. They wanted to educate their congregation into a better understanding of lesbian commitment and they saw the event as part of their wider lesbian politics:

Celia: And we also carefully wrote what we were saying to one another, which we did not call vows. We called [them] pre-empts I think.

Rachel: Affirmation.

Celia: Yes it was an affirmation of partnership, yes that is true.

Rachel: We called them affirmations. We will always agree on absolutely everything - to make public declaration to private commitment.

Celia: $\quad$ It did take a vast amount of time.

Celia: We worked out that the celebrant would say various things, people would speak then we would exchange those affirmations and rings. And all of this we had rehearsed as well.

Rachel: We had a dress rehearsal that afternoon didn't we? 
Celia: $\quad$ Yes and having marched in to Handel's water music we skipped out to Dusty Springfield's 'I only want to be with you' amidst people blowing bubbles, soap bubbles that we provided them with. (Emphasis added - aged 45 and 58, administrative employment/ retired, relationship of 6 years)

While many couples (in all categories) were anxious not to copy heterosexual conventions only one couple spoke about an extravagantly queer celebration:

Fran: $\quad$ I think it was, it was important to us that it was kind of self-aware of how, how can I put it, yes it was very important that it was aware, that it was very queer really, and it was very queer. And being both clearly a wedding at the same time. Neither of us really wanted to sit round in a circle in a wood holding flowers and having poems read out which would have been quite sickly. And at the same time we did not want to do something that was entirely traditional and just aping an unself-aware copy of something. So we had something that was a mixed event. (Aged 39, professional, relationship of 12 years)

For these couples a major part of the politics of what they were doing was in the display element of their wedding. From this perspective a very quiet affair with very few witnesses was politically pointless because it perpetuated the invisibility of gay and lesbian relationships. So although they wrestled with the problem of endorsing heterosexual values, they countered this through the very public character of their ceremonies.

These four styles of wedding therefore reflect very different political inflections. The large, planned, highly public affair proclaimed that homosexual love should be displayed and widely admired or understood. The minimalists saw political statements as residing in private values, a lack of display, and a quiet commitment to lesbian or gay lifestyles. The regular weddings wanted to blend gay and lesbian values and lifestyles into established rituals in order to claim the significance that goes with heterosexual ceremonies, while simultaneously inserting statements about equality, respect and true committed love. The religious group mainly wanted this too, but with the extra dimension of a claim on the recognition of God or some other deity.

\section{Conclusion}

The issue of whether civil partnership is, or is not, akin to heterosexual marriage has been fairly thoroughly aired (Bech, 1992; Donovan, 2004; Jeffreys, 2004; Wise and Stanley, 2004; Harding, 2006). Other studies have also researched the views of gay men and lesbians on the desirability 
or otherwise of some kind of state recognized legal same-sex union (Weeks et al., 2001; Yip, 2004; Lanutti, 2005; Clarke et al., 2006, 2007). However these studies have drawn their samples from general populations of non-heterosexuals by which I mean that the people interviewed were not specifically those who had 'married' or were planning to marry. In the study carried out by Weeks, Heaphy and Donovan for example, only a minority of the 96 individuals they interviewed (in 1995/6) had gone through commitment ceremonies or regarded themselves as 'married'. The study by Clarke, Burgoyne and Burns was also designed to capture the views of same-sex couples but they were not necessarily couples who had undergone a ceremony or who planned to do so. Those studies therefore reflect a range of views about commitment ceremonies, legal recognition and civil partnership, and emphasize concerns about whether marriage might deradicalize and normalize transgressive sexualities. The difference with the study reported here is that we identified couples who were in favour of marriage in some form and so we were able to search more deeply into how their political dilemmas were worked through at a practical and personal level. In a way, the people we interviewed were right in the centre of a personal, moral and political dilemma; they were not on the outside looking in nor were they speaking in terms of principles alone; rather they spoke from the basis of on-going and changing practices. This does not make their views ethically or politically superior; rather what matters is that their stories allow us to see how political principles take shape when confronted with difficult personal decisions. The following two comments reveal precisely this process:

Jen: I remember one guy, a colleague, saying to me that sometimes you do need to separate the personal from [the political] in your life and that to me did make some kind of sense, because I could rationalize what I was doing in my mind. I could see that there were problems with what we were doing, but at this time in my life it was really beneficial and I think for our, well for my family and our network of friends it was as political as far as we could have taken them at that time - and as political as we wanted to go ... our gay friends thought we were really brave but we didn't feel brave. It didn't, did it? I think it was the high-heels you know! (Aged 38, professional, relationship of 5 years)

Penny: I'd already been thinking about it [civil partnership] but something that changed at that point was when a heterosexual friend said something about being really proud to say she wasn't married. And then we had a conversation about that and actually to be heterosexual and to refuse to get married because you're a woman and you don't want to belong to a man is, is really important. But that's completely different from actually two women getting 
married. It's not about belonging in that kind of way, and it's about saying we're equal with heterosexuals, our relationship is as important as heterosexual relationships. (Aged 34, professional, relationship of $5 \frac{1}{2}$ years)

These quotations represent clearly the kinds of ethical and political journey that many couples in our study undertook. What seems to be apparent in these comments is the way in which heterosexual marriage is constantly framed as a point of reference. This rehearsal of the desire to be disassociated from heterosexual norms suggests that same-sex marriages are defined as much in terms of resistance as in terms of positively constructing recognized non-heterosexual lifestyles. This common trope (of setting oneself against heterosexual marriage) signifies the political context in which these ceremonies are taking place, in other words it is clear that there is an important on-going struggle to create an alternative form of union and a deep seated resistance to co-option and normalization.

In this regard our British sample does seem to be more politically conscious than Lewin's sample, which she describes as engaging in a form of 'unconscious resistance' (1998: 241). It also seems different from Hull's sample because she too finds the political significance of her interviewees' weddings as residing in symbolic resistance 'regardless of how their primary creators (the couples) describe their intentions' (2006: 73). So both Lewin and Hull go beyond what their couples actually say in order to find a greater political salience for same-sex weddings. However, with our sample there really seemed to be no need to do this because of the highly politicized awareness of the individuals we interviewed. Our couples were consciously weaving their politics, their personal desires and their attentiveness to those they cared about, into their own wedding rituals. For some 'being political' meant demonstrating equality and sharing in the fabric of their ritual. For others it meant displaying lesbian or gay love and commitment as loudly as possible in their local community. For yet others it meant holding a religious ceremony. All of these decisions were compromises between competing principles and desires and clearly we found diversity in the kinds of ceremony people chose. Yet ultimately the most significant thing that I felt emerged from hearing about these plans and decisions was the recognition that lesbians and gay men were shaping their weddings into conscious reflections of the kind of life-style they wished to endorse and progress.

\section{Acknowledgements}

I would like to thank all the individuals who participated in this study and also Beccy Shipman and Jennifer Mason who worked with me on this project. I am also very grateful to the three anonymous reviewers whose criticisms of the original version of this article were trenchant but offered in a very supportive 
and constructive fashion. Finally my thanks go to the ESRC for funding the project.

\section{Notes}

1. Civil partnership is not exactly the same a heterosexual marriage in the UK and some people argue that this means that it is a lesser legal status with the 'superior' variety preserved for heterosexual couples. However, in legal terms there is virtually no difference.

2. On 13 October 2004, Michael White, political editor of the Guardian wrote 'The government yesterday moved to rescue its civil partnership bill from unworkable 'wrecking' amendments in the Lords'. On the same day Sandi Toksvig (a well known lesbian comedian) wrote in the same paper under the heading 'Even now I doubt the bill will become law'.

3. I use the term married throughout this article because it is the term that most of the participants in the study used and because colloquially it is so much easier than always referring to civil partnership. Some participants did not like the word however and I apologize to them.

4. In England and Wales a number of progressive local authorities (e.g. Greater London, Manchester, Leeds, and Brighton) created a register for same-sex couples where they could enter their names in order to give their relationship a recognized status. This process could be accompanied by a commitment ceremony too, although many commitment ceremonies were held entirely independently of the registration process. Partnership registration did not afford much in the way of legal rights although, had civil partnership not been introduced quite quickly afterwards, it might have become a means of levering more civil rights out of the courts. Although same-sex couples are entitled to continue the practice of non-legal commitment ceremonies, partnership registration is no longer available.

5. Jack Straw, then Home Secretary stated: '[Marriage is] . . . about a union for the procreation of children, which by definition can only happen between a heterosexual couple. So I see no circumstances in which we would ever bring forward proposals for so-called gay marriages'. (The Times, 2 October 2000).

6. The study, funded by the ESRC ref R000230418, was called 'Gay and Lesbian Marriage: An Exploration of the Meanings and Significance of Legitimating Same-Sex Relationships'. The research team consisted of Carol Smart, Jennifer Mason and Beccy Shipman.

7. Gay Times is a monthly magazine with a circulation of 55,000 on average; Diva has a monthly circulation of 35,000. Although Gay Times addresses both gays and lesbians it is regarded as mostly having a male readership, while Diva is focused on women.

\section{References}

Bech, H. (1992) 'Report from a Rotten State: "Marriage" and "Homosexuality" in "Denmark"', in K. Plummer (ed) Modern Homosexualities, pp. 134-49. London: Routledge.

Clarke, V., Burgoyne, C. and Burns, M. (2006) 'Just a Piece of Paper? A 
Qualitative Exploration of Same-Sex Couples' Multiple Conceptions of Civil Partnership and Marriage', Lesbian \& Gay Psychology Review 7(2): 141-61.

Clarke, V., Burgoyne, C. and Burns, M. (2007) 'Romance, Rights, Recognition, Responsibilities and Radicalism: Same-Sex Couples' Views on Civil Partnership and Marriage', in V. Clarke and E. Peel (eds) Out in Psychology: Lesbian, Gay, Bisexual, Trans and Queer Perspectives, pp. 173-93. Chichester: John Wiley \& Sons.

Donovan, C. (2004) 'Why Reach for the Moon? Because the Stars Aren't Enough', Feminism \& Psychology 14(1): 24-9.

Finch, J. (2007) 'Displaying Families', Sociology 41(1): 65-81.

Harding, R. (2006) “"Dogs Are 'Registered', People Shouldn't Be”: Legal Consciousness and Lesbian and Gay Rights', Social \& Legal Studies 15(4): $511-33$.

Hull, K. (2006) Same-Sex Marriage: The Cultural Politics of Love and Law, Cambridge: Cambridge University Press.

Jeffreys, S. (2004) 'The Need to Abolish Marriage', Feminism \& Psychology, 14(2): 327-31.

Lannutti, P. (2005) 'For Better of Worse: Exploring the Meanings of Same-Sex Marriage Within the Lesbian, Gay, Bisexual and Transgendered Community', Journal of Social and Personal Relationships 22(1): 5-18.

Lewin, E. (1998) Recognizing Ourselves: Ceremonies of Lesbian and Gay Commitment. New York: Columbia University Press.

Pahl, R. and Spencer, L. (2004) 'Personal Communities: Not Simply Families of "Fate" or "Choice", Current Sociology 52(2): 199-221.

Smart, C. (2007) 'Same Sex Couples and Marriage: Negotiating Relational Landscapes with Families and Friends', The Sociological Review 55(4): 687-702.

Weeks, J. (2007) The World We Have Won. London: Routledge.

Weeks, J., Heaphy, B. and Donovan, C. (2001) Same Sex Intimacies. London: Routledge.

Wise, S. and Stanley, L. (2004) 'Beyond Marriage: "The Less Said about Love and Life-Long Continuance Together the Better"', Feminism \& Psychology 14(2): $332-43$.

Yip, A. K. T. (2004) 'Same-Sex Marriage: Contrasting Perspectives among Lesbian, Gay and Bisexual Christians’, Feminism \& Psychology 14(1): 173-80.

\section{Biographical Note}

Carol Smart is a professor of sociology in the School of Social Sciences, University of Manchester, UK. She is co-director of The Morgan Centre for the Study of Relationships and Personal Life. Address: School of Social Science, University of Manchester, Arthur Lewis Building, Oxford Road, Manchester, Ml3 9PL, UK. [email: Carol.Smart@Manchester.ac.uk] 